\section{Genetic weaponry?}

SIR - The problems of implementing the Helsinki accords in Soviet Russia have been raised once more in your issue of 15 February (p.437) where the case of David Goldfarb was mentioned. I have known David Goldfarb for many years. He was head of the Laboratory of Molecular Genetics of Bacteria and

Bacteriophage of the Soviet Academy of Sciences. He has asked to emigrate to Israel and a visa was denied on the grounds that "he had access to classified work".

David Goldfarb was never involved in classified work and did not even have security clearance - as so many scientists in Soviet Russia have. He worked on the genetics of bacteria and bacteriophage. If such research is classified, it means that Soviet Russia intends to use molecular genetics for biological warfare.

So far as is known, the USSR Academy of Sciences is consulted when a scientist asks for an emigration visa. One wonders if the Academy will officially and openly subscribe to the decision of the Soviet authorities according to which molecular genetics is a potential weapon and a military secret.

ANDRE LWOFF

Institut Pasteur, Paris, France

\section{NRPB and risk}

SIR - It must be admitted that one does not know what happens within an organization without being a part of it. It is equally true that being a part does not automatically make one a reliable critic of it. We have these assertions in mind upon reading $\mathrm{Mr} \mathrm{S}$. G. Goss's letter on risks at the National Radiological Protection Board (Nature 289, 316 ; 1980).

We have the highest respect for the scientific integrity of Sir Edward Pochin and the late Dr G. W. Dolphin, and their thoughtful attempts to publish reliable information on radiation risks.

We further believe that this view is shared by other US colleagues who have had the opportunity of interacting with these two. Derogatory evidence would have to have a decidedly firmer foundation than that offered in the Goss letter to change this viewpoint. WILLIAM J. BAIR ROY C. THOMPSON Herbert M. PARKer Battelle Pacific Northwest Laboratories, Richland, Washington, USA

\section{Conservation sites}

SIR - In his letter of 12 March 1981, Dr C. Muir criticises actions and advice of the Nature Conservancy Council (NCC) over Sites of Special Scientific Interest (SSSI) on the grounds that such sites are misguidedly chosen to protect endangered species, because species extinction is a natural and inevitable process; and that the site notification procedure imposes an unacceptable financial burden on landowners. The NCC does not notify SSSIs from "caprice"' but because Parliament in its wisdom conferred this duty upon us, as a key part of a national strategy for nature conservation. We continue to do this because a very large number of concerned people believe that SSSIs are important to the conservation of wildlife and physical features.

Most extinctions during the last 2,000 years have been man-induced, and it is this accelerated loss that we are trying to stem. By
$2000 \mathrm{AD}$ the world will have lost no fewer than one million of the plant and animal species existing today, mainly through habitat destruction and over-exploitation. In Britain many indigenous species could become extinct. Whether this is held to be evolution or not is irrelevant: the fact is that many people do not wish such losses to occur and look to NCC and other bodies to prevent them.

SSSIs are in any case not chosen just for the presence of rare or endangered species, but to give a national network of important seminatural habitats. Many are selected quite separately for the importance of their geological and physiographic features. The term "scientific interest" is interpreted broadly as the value of the biological and physical attributes of a site to that informed sector of society which has a concern for such phenomena. The NCC has defined criteria for evaluation of these attributes based on the full range of public interest involved, which is clearly wider than scientists alone.

The SSSI device is one of the few means available for defending the important areas for nature conservation but its actual inadequacy in this respect is currently the subject of lengthy parliamentary debate on the Wildlife and Countryside Bill. Our concern is indeed to safeguard these sites in perpetuity. It is a staggeringly narrow and mechanistic view which holds that once "objects or phenomena" have been "studied" they are of no further value to science and can, by implication, be allowed to disappear. And beyond this, who has the confidence to assert that all possible knowledge has been gleaned from any object or phenomenon?

The responsibility of government to cater for nature conservation as a public interest is not, in a democratic society, altered by the fact that some people find the resulting measures inconvenient to their material interests or irrelevant to their personal beliefs. And just to get things in proportion, the sense of official priority accorded to nature conservation in public affairs is reflected in the $£ 10$ million annual budget of NCC, compared with $£ 700$ million allocated to agricultural support and $£ 9,500$ million to defence.

The NCC has long accepted that when owners and occupiers of land are asked to incur a material loss in order to sustain a nature conservation interest, the principle of compensatory payment is entirely fair. This principle would remain an integral part of the additional site safeguard measures which NCC has been seeking in the Wildlife and Countryside Bill. It seems equally reasonable to ask that owners and occupiers of land accept that they have, on behalf of the nation, a responsibility in stewardship for the national heritage of nature which is now suffering such severe and accelerating losses. We are all increasingly enmeshed in a single society, and when the owners and managers of our national resources ask the taxpayer to help their private circumstances by direct or indirect cash handouts, another point of principle arises. This is that these parties should also accept that such funds are distributed across the whole wide spectrum of taxpayer interests, according to a balance of adjudication through the proper agencies of government, of which NCC is one.

Nature Conservancy Council

D. A. RadcliffE

London SWI, UK

\section{Selling Darwin}

SIR - So much has been written on Darwin and Marx, since Halstead's original diatribe against the use of cladistics in the displays of the Natural History Museum (Nature 288; 208; 1980 ), that I wonder whether these two venerable gentlemen are not now reaching for their pens to set the record straight. Until Nature's Olympian warnings (26 February, p.735) on the "selling out on Darwinism" in the museum (and by association other new evolutionary approaches) one felt safe from the bogies in Halstead's head. Now that they are out and about rather than dead and buried, it is amusing to consider the original error which gave rise to them.

Halstead's polemics "follow like a tedious argument of insidious intent" (T. S. Eliot). His accusation that cladists and proponents of "punctuated equilibria" are furthering the Marxist concept of dialectical materialism reveals his ignorance of the fundamentals of this concept and of Darwinism. If it is necessary to find a biological phenomenon in keeping with dialectical materialism, then Darwin and not "punctuated equilibria" provides a perfect example. According to dialectical materialism (unsullied version) there are two inter-related components to every process in that a gradual accumulation of small quantitative changes leads inevitably to a qualitative change of state. Engel's favourite scientific example was the boiling of water. A qualitative change from liquid to gas only occurs after a sufficient quantitative increase in the thermal agitation of the molecules has taken place. According to popular Darwinism a gradual quantitative accumulation of allelic differences as an adaptive response to a specific environment leads inevitably to a qualitative change of state (the inception of reproductive isolation: speciation). If dialectical materialism upsets Halstead he would do better to dismantle 130 years of Darwinism.

Ironically the precise mechanism by which natural selection could increase reproductive isolation perplexed Darwin and, despite the subsequent attempts of Fisher, Muller and Dobzhansky to explain how this might happen, we have little empirical data. "Let me first say that no man could have more earnestly wished for the success of Natural Selection in regard to sterility than I did, I always felt sure it would be worked out but always failed in detail." (Darwin: letters to Wallace and Huxley). Notwithstanding these doubts and lack of data Darwinism flourishes today as an explanatory mechanism of adaptation that leads to speciation.

The theory of "punctuated equilibria" does not see species formation necessarily as the inevitable consequence of microevolutionary adaptive differences. It dissociates (to an extent) quantitative (microevolutionary) from qualitative (macroevolutionary) phenomena. Thus with regard to the process of adaptation, it is Darwinian. With regard to the process of speciation, there are several current notions (ranging from possible developmental constraints on phylogenetic progress to possible biological effects of saltatory and rapidly spreading changes in genome organization) that, although novel to a degree, leave no room for instant creationism or the demise of Darwin, in the way it is construed. 
They are basically concerned with differential rates of evolutionary change; and the precise role of selection has not, as yet been ascertained. We should not be too surprised if speciation turns out to have an accidental as well as an adaptive component. The imaginative and enquiring spirit of Darwin lives in all except the minds of those with other axes to grind.

I have a feeling that Darwin would be overjoyed at the general acceptability of his concept of fine-grained adaptation under natural selection, and would not be unreceptive to its possible dissociation as a process from that of speciation. Marx, on the other hand, could but grunt that a dissociation of the two processes no longer requires the inevitability of a change of state of one species into another. Gabriel Dover Department of Genetics, University of Cambridge, UK

\section{From the museum...}

SIR - As music is the food of love so surely debate is the nourishment of science, but the crashing cymbals of your leading article of 26 February were a discordant accompaniment to a meagre meal'. Your subsequent article ${ }^{2}$ sets the stage for a more reasoned discussion.

Controversy and debate over the hypotheses associated with the concept of organic evolution have recently received considerable attention. It can hardly be described as a rot permeating just the British Museum (Natural History) but rather the open questioning of evolutionary theory by serious biologists and philosophers - $\mathbf{a}$ fact apparently denied in your first leading article. Furthermore there are clear indications of unease amongst educationalists ${ }^{3,4}$ at the way in which the concept of evolution is being taught, not as an hypothesis open to criticism but as a fact.

Many practising biologists and teachers echo Olson's remark "Evolutionary theory should be treated like any other scientific theory, as a matter for dispassionate and objective study of the evidence available"' 5 . Yet this only reflects the more pungent and provocative comment made by Darwin's "bulldog" over a century ago" . . . the scientific spirit is of more value than its products, and irrationally held truths may be more harmful than reasoned errors. Now the essence of the scientific spirit is criticism"'6.

The views of many scientists in this museum are encapsulated in a quotation from the museum's "recent brochure":

Biologists try to reconstruct the course of evolution from the characteristics of living animals and plants and from fossils, which give a time-scale to the story. If the theory of evolution is true, the features used to classify species in groups... were acquired by the common ancestor of the group and inherited by the living descendants .... In this light, the groupswithin-groups of classification are seen as the descendants of more or less remote common ancestors. And classifying animals and plants is a way of expressing ideas about the course of evolution. This is why classification is interesting and important to biologists, and why the work of classifying is never finished. For new discoveries lead to new ideas about the course of evolution.

Our understanding of the theory of evolution is that it is an amalgam of many subsidiary hypotheses, related not only to the patterns of organic diversity but also to the mechanisms whereby they arise. Here we are faced with a core theory and its protective satellite belts. Clearly various aspects of these hypotheses have been criticized and improved upon, and there is no reason to believe that this evolution has stopped, nor should we pretend that it has stopped. As practising systematists we recognize and we do not underestimate the enormous heuristic value of the theory as a stimulus to research.

The theory of evolution must surely be considered an "open question" and we therefore agree that "in the public presentation of science, it is proper whenever appropriate to say that disputed matters are in doubt". We cannot see, however, how the views expressed in the museum's brochure indicate any divergence from such an objective. Rather, they make a positive statement about the utility of the theory as an explanation for the diversity of life.

P.H. GREENWOOD

Department of Zoology, J. F. PEAKE

British Museum (Natural History)

London SW7, UK.

1. Nature 289, 735 (1981)

2. Nature 290, 75-76 (1981)

3. Hutchinson, C. Biologist 27, 252-256 (1980)

4. Harper, G. H. School Science Review 87, 258-268 (1977). Olsen, E. C. The Evolution of Life (Weidenfeld and Nicolson, London, 1965).

6. Huxley, T. S. The Coming of Age of the "Origin of Species" (reprinted in Darwiniana; Macmillan, Species 1907)

SIR - Dr Colin Patterson ${ }^{1}$ says that cladistics is "not about evolution". Cladistics may therefore be considered essentially a method of classification. Based on morphological characters it arranges taxa into a hierarchy and the hierarchy itself has no necessary phylogenetic implications ${ }^{2}$. Since cladistic classifications are based on "derived" similarity, it seems to have been accepted ${ }^{3}$ that they may resolve the classification hierarchy more fully than traditional classifications, which are based on "clustering" similarity .

If this is all there is to cladistics then at least its taxonomic substance seems uncontroversial. However, any such hierarchical classification, whilst practically useful, is essentially nonscientific ${ }^{5}$, as the aim of science is to explain simple taxonomic relations, then to test the explanation (scientific theories) to see if they make sense ${ }^{6}$. Evolutionary theory is one such scientific theory?

Cladistic method can be incorporated into evolutionary theory by simply accepting that the cladistic hierarchy represents an assumed time axis, a view taken by Hennigian cladists. A historical sequence is "predicted" from the morphology of organisms and in context of Popperian concepts of science, cladists have gone on to compare the congruence of such predicted sequences with other such sequences based on different, semi-independent lines of evidence, such as historical geography ${ }^{8}$.

However, stratigraphy can also be used constructively in such comparisons to call into question the sequence of taxa presented by cladograms and thus to test the usefulness of the hypothesis outlined above ${ }^{9}$.

Cladists to date have applied the concept of testing mainly from an internal perspective of character analysis ${ }^{10}$, and historical time-space coordinates of taxa have in general been ignored. The cladogram has thus been regarded as absolute, whilst evidence from stratigraphy, because it is incomplete, has been recognized as relative - and apparently therefore as worthless ${ }^{11}$. Little attempt has been made to hold the cladistic system itself up to test. It seems to have been overlooked that cladistic classification may make morphological evidence seem convincingly complete, even though it is not actually complete. I do not understand how a system that is relative (cladogram) can be assumed to be absolute and thus used universally to ignore or "refute" historical evidence that is actually true $^{13}$. The view promulgated here regards both sets of evidence as relative, and thus as commensurable. Cladograms present a relative sequence and stratigraphy presents a relative sequence, and both have their own semiindependent corroborators and falsifiers. In actual practice the testing role of stratigraphy would therefore be difficult, a sign of a mature science 9,12 ; in some cases the stratigraphy may be trusted more than the cladogram, in others the cladogram may be relatively well corroborated 13

It is, on the other hand, naively easy to question the cladistic system as a basis for delimiting species. Since cladistic hierarchies reflect characters of organisms, and since such characters are expressed as a hierarchy of proper sub-classes (monothetic sets) ${ }^{4}$, a logical consequence is that classes cannot be discriminated from individuals within the context of character analysis. Men and women form cladistically distinct taxa, and pregnant women a taxon nested within women as a whole. Straightforward genealogical observation refutes this, since a pregnant lady can deliver a son and return to her generalized condition. This argument may seem facile but for the fact that one cladist has recently described several new species out of what many evolutionists might take to be sub-specific populations ${ }^{14}$. At any rate there is a potential danger of over-splitting taxa.

My view differs from some of my colleagues in that I maintain cladistics is about evolution and that any sensibly testable system will recognize that evolution is a complex, mature theory, requiring complex modes of testing beyond "naive falsificationism". Basically I consider evolution and the fossil record as very much the proper context for cladistics and not the converse. It is surely commonsense to use historical evidence to examine history and not to view it askance through a haze of global aristotelian philosophy of character analysis, as transformed cladists appear now to be doing. Transformed cladists may justly have rediscovered Aristotle, but if they decide to wipe out Galileo they reject not only Darwin but all of modern science ${ }^{12}$. CHRISTOPHER HILL

Department of Palaeontology,

British Museum (Natural History), London SW7, UK

1. Patterson, C. Nature 288, $430(1980)$

2. Platnick, N. I. \& Cameron, H. D. Syst. Zool. 26, $380-385$ (1977).

Mayr, E. Z. Zool. Syst. Evol forsch. 12, 94 -128 (1974).

4. Hill, C. R. \& Crane, P. R in Problems of Phylogenetic Reconstruction (eds Joysey, K. A. \& Friday, A. E.) (Academic, in the press)

Hull, D. L. Evolution 21, $174-189$ (1967); Syst Zool. 17 438 - 457 (1968); A Rev. Ecol. Syst. 1, $19-54$ (1970).

6. Popper, K. R. The Logic of Scientific Discovery (Hutchinson, Londion, 1959).

Popper, K. R. New Scient. 87, 611 (1980)

8. Nelson, G. J. \& Platnick, N. 1. Bioscience 30, $339-343$ (1980).

9. Lakatos, 1. Proc. Aristotelian Soc, 69, 149 - 186 (1968).

10. Gaffney, E. S. in Phylogenetic Analysis and Paleontology (eds Cracraft, J. \& Eldredge, N.) $79-111$ (Columbia University Press, New York)

11. Nelson, G. J. Syst. Zool, 27, 324 - 345 (1978).

12. Feyerabend, P. Against Method. (Verso, London, 1975).

13. Manuscript submitted to Science.

14. Rosen, D. E. Bull. Amer. Mus. Nat. Hist. 162,275- 278 (1979). 